\title{
Cluster analysis of rat pancreatic islet gene mRNA levels after culture in low-, intermediate- and high-glucose concentrations
}

\author{
M. Bensellam • L. Van Lommel • L. Overbergh • \\ F. C. Schuit • J. C. Jonas
}

Received: 6 August 2008 / Accepted: 19 November 2008 / Published online: 23 January 2009

(C) Springer-Verlag 2009

\begin{abstract}
Aims/hypothesis Survival and function of insulin-secreting pancreatic beta cells are markedly altered by changes in nutrient availability. In vitro, culture in 10 rather than $2 \mathrm{mmol} / \mathrm{l}$ glucose improves rodent beta cell survival and function, whereas glucose concentrations above $10 \mathrm{mmol} / \mathrm{l}$ are deleterious.

Methods To identify the mechanisms of such beta cell plasticity, we tested the effects of $18 \mathrm{~h}$ culture at 2, 5, 10 and $30 \mathrm{mmol} / \mathrm{l}$ glucose on the transcriptome of rat islets precultured for 1 week at $10 \mathrm{mmol} / \mathrm{l}$ glucose using Affymetrix Rat 2302.0 arrays.

Results Culture in either $2-5$ or $30 \mathrm{mmol} / 1$ instead of $10 \mathrm{mmol} / \mathrm{l}$ glucose markedly impaired beta cell function, while little affecting cell survival. Of about 16,000 probesets reliably detected in islets, some 5,000 were significantly up- or downregulated at least 1.4 -fold by glucose. Analysis of these probe-sets with GeneCluster software identified ten
\end{abstract}

Electronic supplementary material The online version of this article (doi:10.1007/s00125-008-1245-z) contains supplementary material, which is available to authorised users.

M. Bensellam · J. C. Jonas $(\bowtie)$

Unit of Endocrinology and Metabolism, Faculty of Medicine,

Université catholique de Louvain,

Avenue Hippocrate 55 (UCL5530),

1200 Brussels, Belgium

e-mail: jean-christophe.jonas@uclouvain.be

L. Van Lommel • F. C. Schuit

Gene Expression Unit, Department of Molecular Cell Biology,

Katholieke Universiteit Leuven,

Leuven, Belgium

L. Overbergh

Laboratory for Experimental Medicine and Endocrinology,

University Hospital Gasthuisberg,

Katholieke Universiteit Leuven,

Leuven, Belgium
mRNA profiles with unidirectional up- or downregulation between 2 and 10, 2 and 30, 5 and 10, 5 and 30 or 10 and $30 \mathrm{mmol} / \mathrm{l}$ glucose. It also identified eight complex V-shaped or inverse $\mathrm{V}$-shaped profiles with a nadir or peak level of expression in 5 or $10 \mathrm{mmol} / \mathrm{l}$ glucose. Analysis of genes belonging to these various clusters using Onto-express and GenMAPP software revealed several signalling and metabolic pathways that may contribute to induction of beta cell dysfunction and apoptosis after culture in low- or high- vs intermediate-glucose concentration.

Conclusions/interpretation We have identified 18 distinct mRNA profiles of glucose-induced changes in islet gene mRNA levels that should help understand the mechanisms by which glucose affects beta cell survival and function under states of chronic hypo- or hyperglycaemia.

Keywords Apoptosis - Beta cell · Cluster analysis .

Endoplasmic reticulum stress response $\cdot$ Phenotypic plasticity

\author{
Abbreviations \\ $\left[\mathrm{Ca}^{2+}\right]_{\mathrm{i}}$ Intracellular $\mathrm{Ca}^{2+}$ concentration \\ ER Endoplasmic reticulum \\ G10 $10 \mathrm{mmol} / \mathrm{l}$ glucose (G2, G5, G20 and G30 \\ GSIS Glucose-stimulated insulin secretion \\ ISR Integrated stress response \\ UPR Unfolded protein response
}

\section{Introduction}

The ability of pancreatic beta cells to secrete insulin in response to nutrient stimulation depends on adequate expression of genes important for glycolysis, mitochondrial metabolism and 
insulin biosynthesis, such as preproinsulin, Glut2 (also known as Slc2a2) and glucokinase, and on the repression of genes potentially deleterious to beta cell function [1], including hexokinase 1 and lactate dehydrogenase A [2]. Besides acutely regulating insulin biosynthesis and secretion, subacute and prolonged changes in nutrient availability exert pleiotropic effects on the beta cell phenotype, such as altered function, survival, growth and differentiation [3-6].

In vitro, rat islet glucose-stimulated insulin secretion (GSIS) is optimally preserved by culture in the presence of $10 \mathrm{mmol} / \mathrm{l}$ glucose (G10). After culture at low non-stimulating glucose concentrations of $2 \mathrm{mmol} / \mathrm{l}(\mathrm{G} 2)$ and $5 \mathrm{mmol} / \mathrm{l}$ (G5), subsequent acute GSIS is reduced independently from changes in insulin content [7,8]. On the other hand, culture in a high glucose concentration of $30 \mathrm{mmol} / \mathrm{l}$ (G30) increases glucose sensitivity while decreasing the islet insulin content and the maximal rate of insulin secretion $[9,10]$. Beta cell apoptosis is also minimal after culture in G10 and significantly increased after culture in either lower or higher glucose concentrations [9-14]. Thus, in vitro, glucose stimulation from G2 to G10 improves beta cell survival and function whereas glucose concentrations above G10 are deleterious.

Although the mRNA levels of a few pro- and anti-apoptotic genes (Myc [also known as $c-M y c$ ], Hmoxl) display a similar V-shaped glucose-response curve [13, 15, 16], the molecular bases of these complex glucose effects on the beta cell phenotype remain unclear. Large-scale analyses of beta cell gene expression have demonstrated that the glucose-dependent preservation of beta cell function between G3 and G10 is correlated with the regulation of numerous genes $[5,8,17$, 18]. Other studies testing the effects of higher glucose concentrations generated new hypotheses about the mechanisms of beta cell glucotoxicity [19, 20]. However, except for one study on the effects of diazoxide on glucose-induced changes in islet gene expression [21], most studies suffer from the fact that gene mRNA levels between only two glucose concentrations are compared, namely either low and high, low and intermediate or intermediate and high. Furthermore, inter-study comparison of gene expression at a given glucose concentration is hampered by the use of various beta cells with different degrees of proliferation, differentiation and glucose sensitivity [22].

Therefore, to evaluate how glucose stimulation affects the beta cell phenotype differently depending on its concentration, we tested the effects of culture in G2, G5, G10 and G30 on key events of glucose stimulus-secretion coupling in beta cells, as well as islet cell apoptosis and gene mRNA levels. Cluster analysis and functional categorisation of glucoseaffected genes allowed identification of signalling and metabolic pathways that are enriched in genes with a similar mRNA profile and are potentially involved in the complex glucose regulation of beta cell function and survival.

\section{Methods}

Reagents Diazoxide and $\mathrm{Na}^{+}$-azide were purchased from Sigma (St Louis, MI, USA). All other reagents were from Merck (Darmstadt, Germany).

Islet isolation and culture Islets were isolated from the pancreas of $\sim 200 \mathrm{~g}$ male Wistar rats (Faculty of Medicine animal facility, Université catholique de Louvain) as described [16]. They were cultured for 1 week in serum-free RPMI 1640 medium (Invitrogen, Carlsbad, CA, USA) containing $10 \mathrm{mmol} / 1$ glucose, $5 \mathrm{~g} / 1 \mathrm{BSA}$ (fraction V; Roche, Basel, Switzerland), $100 \mathrm{IU} / \mathrm{ml}$ penicillin and $100 \mu \mathrm{g} / \mathrm{ml}$ streptomycin (Invitrogen). To avoid central necrosis, islets with a diameter $>150$ to $200 \mu \mathrm{m}$ were routinely discarded. These pre-cultured islets were then cultured in the same medium containing G2, G5, G10, 20 mmol/l glucose (G20) or G30 and processed for further analysis. All experiments were approved by the local ethics committee for animal experimentation and performed according to the Principles of Laboratory Animal Care.

Islet cell apoptosis Active islet caspases were detected using the fluorescent caspase inhibitor FAM-VADfluoromethylketone (MP Biomedicals, Irvine, CA, USA) as described [23]. Cytoplasmic histone-associated DNA fragments were measured on batches of 30 to 60 islets with a kit (Cell Death Detection ELISA ${ }^{\text {PLUS }}$; Roche Diagnostics, Mannheim, Germany) following the manufacturer's instructions. The presence of apoptotic bodies was checked on islet histological sections stained with haematoxylin and eosin.

Islet function Insulin secretion in culture media was measured by RIA. Total islet protein synthesis during culture was estimated by measuring $\mathrm{L}-\left[3,5-{ }^{3} \mathrm{H}\right]$ tyrosine incorporation (Amersham Biosciences, Amersham, UK) in trichloroacetic acid-precipitated protein extracts [14]. The acute glucoseinduced changes in mitochondrial membrane potential, intracellular $\mathrm{Ca}^{2+}$ concentration $\left(\left[\mathrm{Ca}^{2+}\right]_{\mathrm{i}}\right)$ and insulin secretion, as well as the islet insulin content after culture were measured as described [10].

Oligonucleotide microarray After culture, islet total RNA (1,000 islets per condition) was extracted (absolutely microprep kit; Stratagene, La Jolla, CA, USA) and reverse-transcribed in cDNA (SuperScript Choice System; Invitrogen) using oligodT primers and a T7-RNA-polymerase-promoter site. cDNA was transcribed in vitro and the resulting cRNA was biotinlabelled using a labelling kit (Affymetrix IVT; Affymetrix, Santa Clara, CA, USA), fragmented by 35 min incubation at $94^{\circ} \mathrm{C}$ and hybridised for $16 \mathrm{~h}$ at $45^{\circ} \mathrm{C}$ to a Rat Genome 2302.0 array (Affymetrix). The arrays were then washed, stained with 
streptavidin-phycoerythrin and scanned (3000 GeneScanner; Affymetrix). Overall quality of hybridisation was assessed on the .dat files following manufacturer's instructions. Raw data were analysed using Affymetrix GeneChip Operating Software (GCOS). Signal intensities were scaled using the global scaling method of the statistical expression algorithm taking 150 as target intensity value. Scaling factors were less than three times different from each other in all arrays used. Raw data for the four experiments carried out with different islet preparations are accessible on Gene Expression Omnibus (http://www.ncbi. nlm.nih.gov/geo/, accessed 1 December 2008) under accession number GSE12817.

Real-time RT-PCR Islet total RNA extraction, reverse transcription and real-time PCR were performed as described [14]. Primer sequences, the characteristics of amplicons and the reaction conditions are shown in Electronic supplementary material (ESM) Table 1.

Statistical analysis Results are means $\pm \mathrm{SE}$ for the indicated number of experiments. Statistical significance of differences between groups was assessed by one-way ANOVA and a post-test of Newman-Keuls or Bonferroni.

\section{Results and discussion}

We had previously shown that 1 week pre-culture of rat islets in serum-free RPMI medium containing $5 \mathrm{~g} / 1 \mathrm{BSA}$ and G10 allows recovery from the stress of isolation and disappearance of non-endocrine cells while optimally preserving beta cell survival and function $[10,13,15,16]$. Thus, the glucose-induced rise in $\left[\mathrm{Ca}^{2+}\right]_{\mathrm{i}}$ and stimulation of insulin secretion and protein synthesis in pre-cultured islets were similar to those reported in fresh or overnight-cultured islets $[10,14]$. Furthermore, the glucose regulation of $M y c$ and Hmoxl expression was easier to detect after preculture, due to the strong transient induction of these stressresponse genes following islet isolation $[13,15,16]$. We therefore used such pre-cultured islets to test the effects of glucose on gene expression while avoiding the stress of isolation and early adaptation to culture. We first characterised the effects of glucose on islet cell apoptosis and beta cell response to acute glucose stimulation.

Concentration- and time-dependent effects of glucose on islet cell survival After pre-culture in G10, further culture in lower or higher glucose concentrations time-dependently affected islet cell survival. After $18 \mathrm{~h}$, DNA fragmentation was slightly increased in G2, but remained unaffected in G5, G20 and G30 vs G10 (Fig. 1a). These islets displayed few apoptotic or necrotic cells on histological sections, irrespective of the glucose concentration during culture (Fig. 1b).
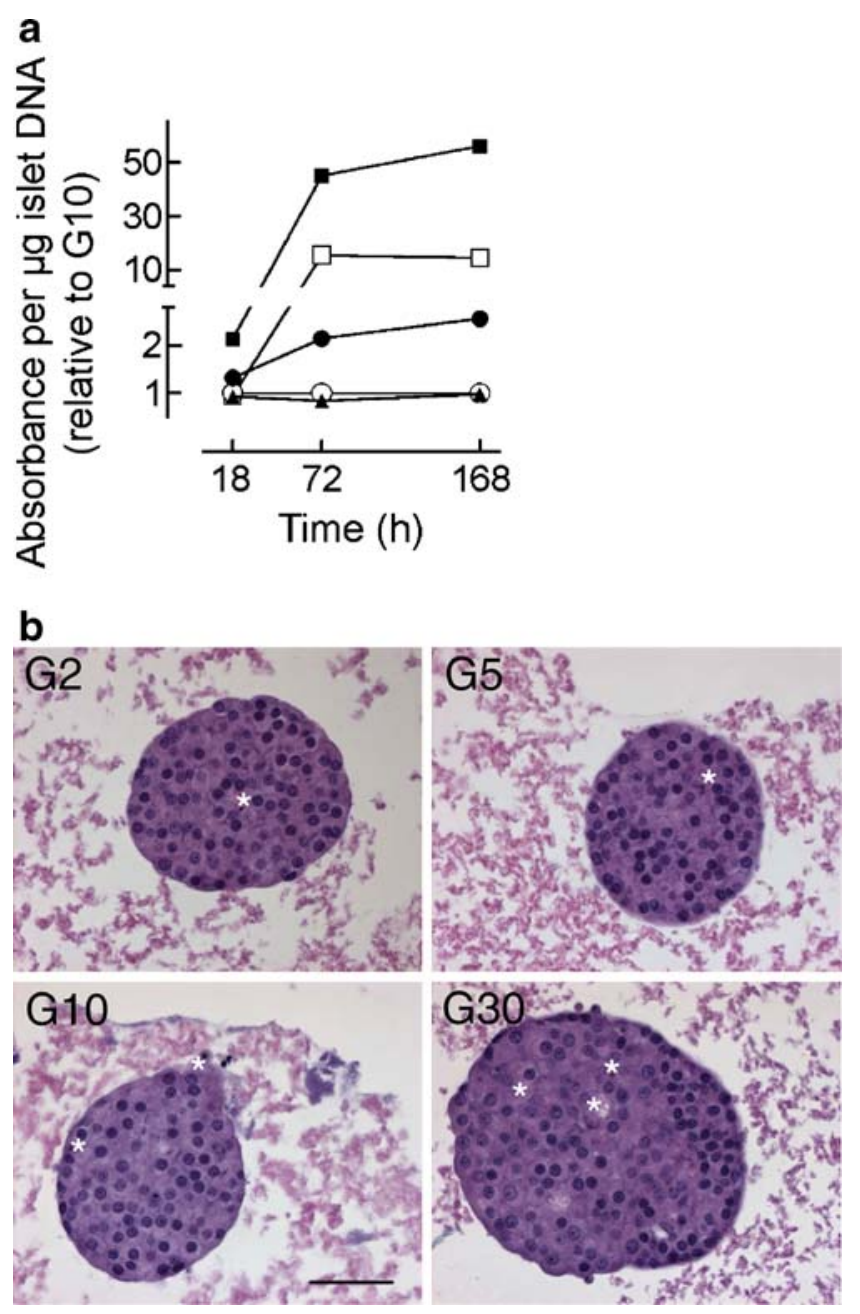

Fig. 1 Concentration- and time-dependent effects of glucose on islet cell survival and morphology. a After 1 week of pre-culture in serumfree RPMI medium containing $10 \mathrm{mmol} / 1$ glucose and $5 \mathrm{~g} / \mathrm{l} \mathrm{BSA}$, rat islets were cultured for up to 7 days in the presence of 2 (black squares), 5 (white squares), 10 (white circles), 20 (black triangles) or 30 (black circles) mmol/1 glucose. Cytoplasmic histone-associated DNA fragments were measured as described in "Methods". Absorbance values $(490-405 \mathrm{~nm})$ were divided by the absorbance of the positive control provided in the kit and corrected for variations in islet DNA content. They were then expressed relative to the value measured in islets cultured in G10. Results are means for two experiments. b Haematoxylin/eosin-stained sections of islets fixed in Bouin's fluid after 1 week pre-culture in G10 and further $18 \mathrm{~h}$ culture in the presence of G2, G5, G10 and G30 as indicated (white stars, apoptotic bodies). The pink precipitate around the islets corresponds to fixed BSA from the culture media. Islets shown are representative of islets used in the four microarray experiments. Scale bar, $50 \mu \mathrm{m}$

Their caspase activity was also unaffected by glucose (islet FAM-VAD-fluoromethylketone fluorescence relative to G10: $1.04 \pm 0.08$ in $\mathrm{G} 2,1.02 \pm 0.06$ in G5, $1.00 \pm 0.05$ in G10 and $0.99 \pm 0.02$ in $\mathrm{G} 30$ [means \pm SE for $13-19$ islets from two experiments]). In contrast, after 3 to 7 days of culture, DNA fragmentation was increased markedly in G2 and G5, unaffected in G10 and G20, and slightly increased in G30 (Fig. 1a). The effects of low glucose did not result from 
a

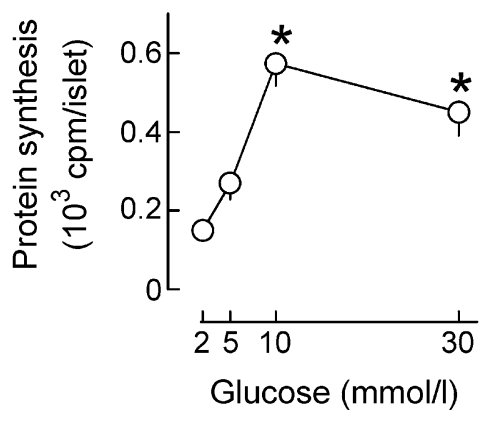

b

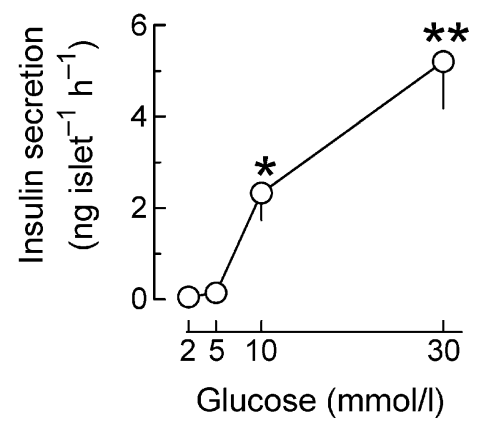

C

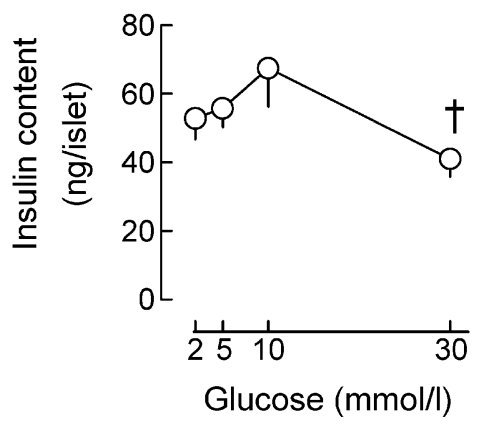

d

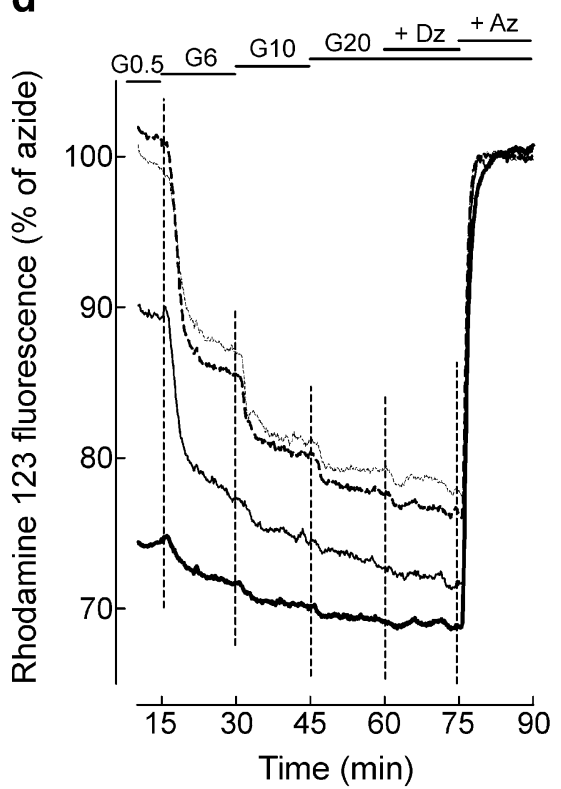

e

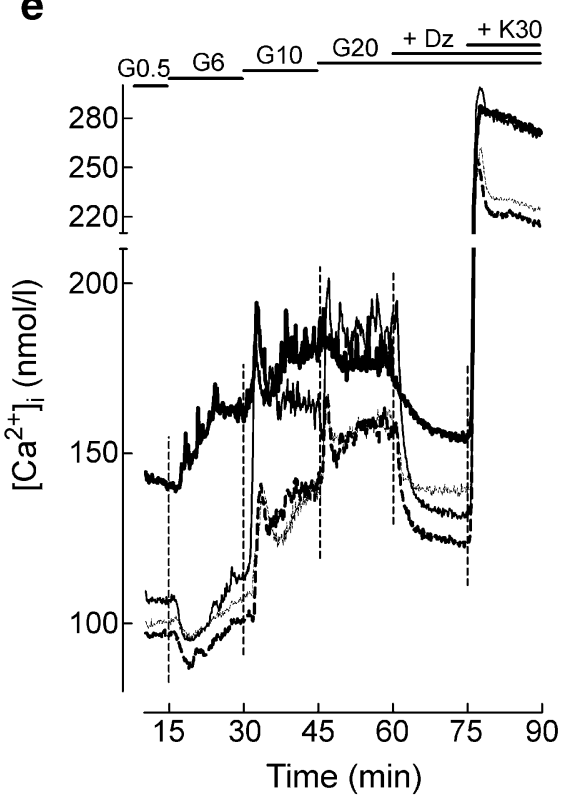

f

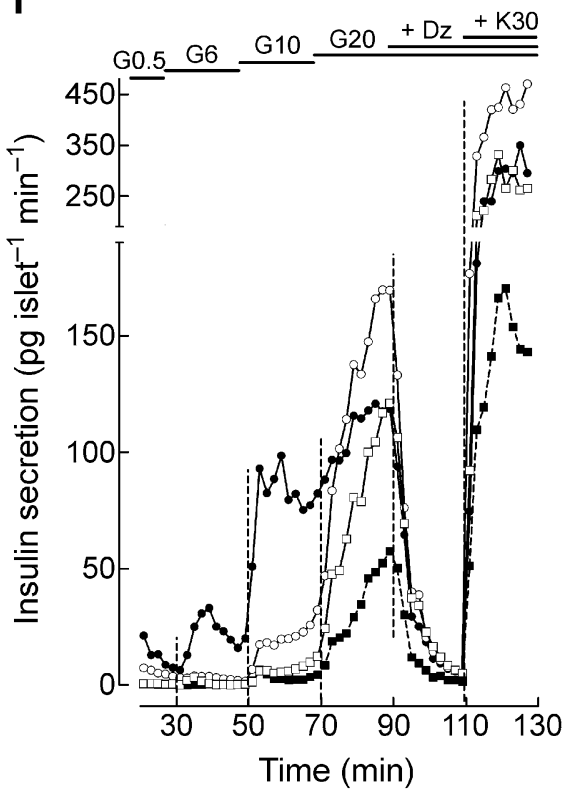

Fig. 2 Effects of increasing glucose concentrations during culture on variables of beta cell function. a, b After 1 week pre-culture in serum-free RPMI medium containing $10 \mathrm{mmol} / \mathrm{l}$ glucose (G10) and $5 \mathrm{~g} / \mathrm{l} \mathrm{BSA}$, total protein synthesis (a) and insulin secretion (b) were measured during a further $18 \mathrm{~h}$ culture in the presence of $2,5,10$ or $30 \mathrm{mmol} / 1$ glucose (G2, $\mathrm{G} 5, \mathrm{G} 10, \mathrm{G} 30)$. Data are means $\pm \mathrm{SE}$ for four to nine experiments. ${ }^{*} p<0.05,{ }^{* *} p<0.01$ vs islets cultured in G2 (one-way ANOVA plus Newman-Keuls test). c-f After culture and eventual loading with rhodamine 123 for $15 \mathrm{~min}$ (d) or furaPE3 acetoxymethyl ester for $2 \mathrm{~h}$ (e) in the presence of the same glucose concentration, the islets were perifused for 15 to $30 \mathrm{~min}$ in Krebs medium containing $0.5 \mathrm{mmol} / 1$ glucose and stimulated by stepwise increases in glucose concentration, followed by addition of $250 \mu \mathrm{mol} / 1$ diazoxide (Dz), as indicated. At the end of the experiments, the islets were treated with $5 \mathrm{mmol} / \mathrm{l}$ azide $(\mathrm{Az})$ in the

complete islet glucose deprivation, as shown by measurements of the media glucose concentration at the end of culture (ESM Table 2).

Concentration-dependent effects of glucose on beta cell function During $18 \mathrm{~h}$ culture of islets pre-cultured for 1 week, glucose markedly stimulated total protein synthesis from $\mathrm{G} 2$ to G10 and insulin secretion from G5 to G30 (Fig. 2a,b), as reported previously [14-16]. Glucose also significantly presence of G20 to maximally depolarise the mitochondrial membrane (d) or with $30 \mathrm{mmol} / \mathrm{l} \mathrm{K}^{+}(\mathrm{K} 30)$ in the presence of Dz and G20 to maximally stimulate $\mathrm{Ca}^{2+}$ influx and insulin secretion $(\mathbf{e}, \mathbf{f})$. c After perifusion, the islets were collected for determination of their insulin content $\left({ }^{\dagger} p<0.01\right.$ vs $\mathrm{G} 10$ by unpaired $t$ test). Rhodamine 123 fluorescence (d) and $\left[\mathrm{Ca}^{2+}\right]_{\mathrm{i}}$ (e) were measured by microspectrofluorimetry. d, e Dotted lines, culture in G2; dashed lines, culture in G5; continuous lines, culture in G10; bold lines, culture in G30; (f) black squares, culture in G2; white squares, culture in G5; white circles, culture in G10; black circles, culture in G30. Please note: a decrease in rhodamine 123 fluorescence corresponds to mitochondrial hyperpolarisation. f Insulin secretion was measured in 2 min effluent collections. Data are means \pm SE (c) or means $(\mathbf{d}-\mathbf{f})$ for four to five independent experiments

affected the islet insulin content (Fig. 2c) and the beta cell response to subsequent acute glucose stimulation (Fig. 2d-f) as in rat islets cultured for several days immediately after isolation [9, 10]. Thus, culture in G2 and G5 vs G10 depolarised the mitochondria at all glucose concentrations and markedly reduced the rise in $\left[\mathrm{Ca}^{2+}\right]_{\mathrm{i}}$ and the stimulation of insulin secretion by glucose and high extracellular $\left[\mathrm{K}^{+}\right]$ despite only slight reduction of the islet insulin content. In contrast, culture in G30 vs G10 hyperpolarised the mitochon- 
Table 1 Maximal probe-set hybridisation signal intensity and present/absent/excluded call for genes specifically expressed in islet cells and genes enriched in acinar, ductal and endothelial cells

\begin{tabular}{|c|c|c|c|c|}
\hline Cell type & Probe-set ID & Gene name & Hybridisation signal intensity & Call \\
\hline \multirow[t]{2}{*}{ Beta cells } & 1387815_at & Insulin & $9607 \pm 1231$ & Present \\
\hline & 1387660_at & Islet amyloid polypeptide & $11199 \pm 1476$ & Present \\
\hline Alpha cells & 136988__at & Glucagon & $11919 \pm 1441$ & Present \\
\hline Delta cells & 1367762_at & Somatostatin & $8705 \pm 520$ & Present \\
\hline PP cells & 1369196_at & Pancreatic polypeptide & $1004 \pm 334$ & Present \\
\hline \multirow[t]{5}{*}{ Acinar cells } & 1369503_at & Amylase 2 , pancreatic & $4 \pm 2$ & Absent \\
\hline & 1387819_at & Elastase 1 & $42 \pm 18$ & Absent \\
\hline & 1387471_at & Elastase 2 & $11 \pm 8$ & Absent \\
\hline & 1369657_at & Carboxypeptidase A1 & $10 \pm 10$ & Absent \\
\hline & 1370084_at & Carboxypeptidase B1 & $11 \pm 8$ & Absent \\
\hline \multirow[t]{3}{*}{ Ductal cells } & 1372691_at & Uridine phosphorylase 1 & $11 \pm 3$ & Absent \\
\hline & 1388074_at & Keratin 20 & $29 \pm 8$ & Absent \\
\hline & 1367581_a_at & Secreted phosphoprotein 1 & $27 \pm 10$ & Excluded \\
\hline \multirow[t]{3}{*}{ Endothelial cells } & 1389255_at & Cadherin 5 & $108 \pm 19$ & Absent \\
\hline & 1382194_at & Factor VIII & $50 \pm 4$ & Present \\
\hline & 1368078 at & Endothelial specific molecule 1 & $31 \pm 10$ & Excluded \\
\hline
\end{tabular}

Values are mean $\pm \mathrm{SE}$

Rat islets were pre-cultured for 1 week in serum-free RPMI medium containing G10 and $5 \mathrm{~g} / 1 \mathrm{BSA}$ and further cultured for $18 \mathrm{~h}$ in G2, G5, G10 or G30

Designation present or absent based on criteria detailed in ESM Fig. 2

Probe-sets listed as present and with a maximal hybridisation signal intensity $<50$ were excluded from further analyses due to their low level of expression

$\mathrm{PP}$, pancreatic polypeptide

dria at all glucose concentrations and markedly increased islet sensitivity to glucose, while reducing the maximal rate of insulin secretion and the insulin content by about $30 \%$. In addition, culture in $\mathrm{G} 30$ increased the islet resting $\left[\mathrm{Ca}^{2+}\right]_{\mathrm{i}}$ by about $20 \mathrm{nmol} / 1$. The glucose sensitivity and resting $\left[\mathrm{Ca}^{2+}\right]_{\mathrm{i}}$ of islets cultured in G20 were intermediate between those measured after culture in G10 and G30 (data not shown). After 3 days of culture in G2 and G5 vs G10, the glucoseinduced $\left[\mathrm{Ca}^{2+}\right]_{\mathrm{i}}$ rise was markedly reduced (ESM Fig. 1). In contrast, $\left[\mathrm{Ca}^{2+}\right]_{\mathrm{i}}$ alterations induced by culture in $\mathrm{G} 30$ were similar to those observed after $18 \mathrm{~h}$.

These results indicate that, after 1 week pre-culture in G10, $18 \mathrm{~h}$ culture in lower or higher glucose markedly alters beta cell function, but hardly affects cell survival, whereas 3 days of culture induces apoptosis and further alters beta cell function to a much larger extent in low than in high glucose. Measuring the effect of glucose on islet gene expression after $18 \mathrm{~h}$ culture could therefore be expected to give some insight into the mechanisms by which changes in nutrient availability affect the beta cell phenotype, while avoiding as much as possible the alterations secondary to apoptosis.

Concentration-dependent effects of glucose on the transcriptome of cultured rat islets Islet gene mRNA levels were measured after 1 week pre-culture and further $18 \mathrm{~h}$ culture in G2, G5, G10 and G30 using Affymetrix Rat 2302.0 oligonucleotide arrays. Out of 31,099 probe-sets on the arrays, 15,910 were reliably expressed in at least one glucose concentration and were selected for further analysis (ESM Fig. 2 gives details of filters used in microarray data analysis). As shown in Table 1, islet cell hormones were all expressed at very high levels, whereas exocrine pancreatic enzymes and genes characteristic of pancreatic ducts and endothelial cells were not reliably expressed. Thus, our preparations of rat islets pre-cultured for 1 week in G10 in the absence of serum were mostly composed of endocrine (alpha, beta, delta and pancreatic polypeptide) cells and were almost free of acinar, ductal and endothelial cells.

Among the 15,910 selected probe-sets, 7,841 ( 50\%) were significantly affected between at least two of the four glucose concentrations tested (one-way ANOVA followed by a test of Bonferroni), among which false discovery rate analysis indicated that less than 200 were false positives (ESM Fig. 3). Of these 7,841 probe-sets, 5,046 were up- or downregulated more than 1.4-fold, 1,213 more than twofold and 145 more than fourfold. Although the majority were exclusively upregulated $(2,113)$ or downregulated $(2,522)$ by glucose, 411 probe-sets $(\sim 8 \%)$ were affected in a complex manner, being both upregulated and downregulated in different parts of the glucose-response curve. The resulting mRNA expression profiles were $\mathrm{V}$-shaped or inverse- $\mathrm{V}$-shaped, with a nadir or peak level of expression in G5 or G10. Consequently, a 
Table 2 The 40 genes most affected by glucose

\begin{tabular}{|c|c|c|c|c|c|c|}
\hline Gene symbol & Probe-set ID & $|\mathrm{SLR}|_{\max }$ & G2 & G5 & G10 & G30 \\
\hline \multicolumn{7}{|c|}{ Upregulated genes } \\
\hline Aldob & 1370299_at & 6.90 & $13 \pm 4$ & $8 \pm 4$ & $13 \pm 6$ & $883 \pm 156$ \\
\hline Txnip & 1371131_a_at & 5.59 & $83 \pm 5$ & $115 \pm 10$ & $346 \pm 45$ & $3,882 \pm 470$ \\
\hline Ppp1r3c & 1373108_at & 4.56 & $19 \pm 8$ & $10 \pm 3$ & $6 \pm 2$ & $127 \pm 22$ \\
\hline Myo16 & 1370478_at & 3.91 & $4 \pm 1$ & $8 \pm 2$ & $90 \pm 10$ & $61 \pm 12$ \\
\hline Cckar & 1387700_at & 3.68 & $16 \pm 4$ & $24 \pm 5$ & $184 \pm 27$ & $145 \pm 9$ \\
\hline Mmp13 & 1388204_at & 3.34 & $23 \pm 3$ & $24 \pm 3$ & $30 \pm 3$ & $194 \pm 20$ \\
\hline Pck2 & 1391451_at & 3.18 & $6 \pm 2$ & $43 \pm 1$ & $40 \pm 7$ & $78 \pm 12$ \\
\hline Crem & 1369737_at & 3.13 & $61 \pm 8$ & $62 \pm 6$ & $240 \pm 9$ & $652 \pm 55$ \\
\hline Smgb & 1386964_at & 3.09 & $10 \pm 4$ & $19 \pm 6$ & $80 \pm 11$ & $80 \pm 14$ \\
\hline$A d m$ & 1387219_at & 3.00 & $55 \pm 8$ & $50 \pm 7$ & $28 \pm 4$ & $283 \pm 51$ \\
\hline Gpr6 & 1369792_at & 2.68 & $108 \pm 15$ & $105 \pm 22$ & $312 \pm 36$ & $515 \pm 29$ \\
\hline Gem & 1382351_at & 2.59 & $97 \pm 7$ & $95 \pm 7$ & $423 \pm 53$ & $626 \pm 57$ \\
\hline Gale & 1368074_at & 2.39 & $31 \pm 6$ & $26 \pm 6$ & $54 \pm 2$ & $102 \pm 9$ \\
\hline Fos & 1375043_at & 2.39 & $26 \pm 2$ & $37 \pm 12$ & $92 \pm 7$ & $140 \pm 17$ \\
\hline Hbegf & 1368983_at & 2.32 & $25 \pm 2$ & $20 \pm 1$ & $40 \pm 3$ & $101 \pm 16$ \\
\hline Nod3l & 1380305_at & 2.30 & $46 \pm 4$ & $45 \pm 8$ & $98 \pm 12$ & $266 \pm 8$ \\
\hline \multicolumn{7}{|c|}{ Downregulated genes } \\
\hline$D b p$ & 1387874_at & 4.44 & $932 \pm 115$ & $599 \pm 46$ & $102 \pm 7$ & $51 \pm 7$ \\
\hline Tjp3 & 1378567_at & 4.18 & $104 \pm 9$ & $84 \pm 6$ & $7 \pm 4$ & $15 \pm 3$ \\
\hline Phlda3 & 1375224_at & 3.67 & $523 \pm 28$ & $462 \pm 48$ & $57 \pm 8$ & $37 \pm 5$ \\
\hline Fas & 1384842_s_at & 3.44 & $199 \pm 15$ & $163 \pm 12$ & $22 \pm 5$ & $17 \pm 3$ \\
\hline Sult1d1 & 1369047_at & 3.31 & $128 \pm 28$ & $82 \pm 20$ & $37 \pm 7$ & $17 \pm 2$ \\
\hline$R d m 1$ & 1389453_at & 3.26 & $69 \pm 9$ & $90 \pm 7$ & $18 \pm 7$ & $8 \pm 3$ \\
\hline Ptch1 & 1398614_at & 3.22 & $56 \pm 6$ & $39 \pm 5$ & $17 \pm 4$ & $8 \pm 3$ \\
\hline$G d f 15$ & 1370153_at & 2.82 & $764 \pm 30$ & $737 \pm 181$ & $152 \pm 40$ & $196 \pm 14$ \\
\hline Adcy8 & 1387179_at & 2.81 & $92 \pm 9$ & $82 \pm 4$ & $26 \pm 4$ & $14 \pm 4$ \\
\hline Trib3 & 1370694_at & 2.79 & $835 \pm 45$ & $711 \pm 47$ & $153 \pm 26$ & $202 \pm 15$ \\
\hline Klf15 & 1368249_at & 2.66 & $236 \pm 19$ & $220 \pm 39$ & $128 \pm 10$ & $47 \pm 4$ \\
\hline Mgmt & 1368311_at & 2.54 & $729 \pm 52$ & $870 \pm 45$ & $214 \pm 25$ & $155 \pm 14$ \\
\hline$R T 1-C E 5$ & 1388255_x_at & 2.52 & $130 \pm 33$ & $114 \pm 31$ & $20 \pm 7$ & $22 \pm 7$ \\
\hline Neto 2 & 1392999_at & 2.49 & $105 \pm 6$ & $123 \pm 17$ & $29 \pm 4$ & $32 \pm 4$ \\
\hline Ddit3 & 1369590_a_at & 2.44 & $1,694 \pm 139$ & $1,626 \pm 47$ & $315 \pm 100$ & $310 \pm 60$ \\
\hline Icam1 & 1387202_at & 2.41 & $94 \pm 32$ & $78 \pm 10$ & $20 \pm 14$ & $24 \pm 9$ \\
\hline Uap1l1 & 1381982_at & 2.35 & $673 \pm 57$ & $441 \pm 51$ & $260 \pm 27$ & $145 \pm 10$ \\
\hline Blm & 1382783_at & 2.33 & $126 \pm 5$ & $96 \pm 4$ & $40 \pm 4$ & $29 \pm 4$ \\
\hline Gdf1/Lass1 & 1377506_at & 2.29 & $312 \pm 42$ & $226 \pm 10$ & $101 \pm 13$ & $51 \pm 7$ \\
\hline \multicolumn{7}{|c|}{ V-shaped gene, more up- than downregulated } \\
\hline$G 0 s 2$ & 1388395_at & 2.54 & $227 \pm 14$ & $283 \pm 27$ & $169 \pm 31$ & $1,063 \pm 145$ \\
\hline \multicolumn{7}{|c|}{ V-shaped genes, more down- than upregulated } \\
\hline Mt1a & 1371237_a_at & 4.88 & $4,360 \pm 509$ & $3,767 \pm 704$ & $299 \pm 203$ & $1,251 \pm 97$ \\
\hline$A b c b 1$ & 1370464_at & 3.06 & $45 \pm 5$ & $53 \pm 2$ & $8 \pm 3$ & $30 \pm 10$ \\
\hline Casp4 & 1387818_at & 2.51 & $868 \pm 73$ & $879 \pm 34$ & $172 \pm 13$ & $339 \pm 24$ \\
\hline Hmox 1 & 1370080_at & 2.38 & $1,251 \pm 151$ & $765 \pm 130$ & $264 \pm 83$ & $1,058 \pm 219$ \\
\hline
\end{tabular}

Glucose-affected probe-sets were classified in decreasing order of their maximal absolute signal to $\log _{2}$ ratio ( $\mid$ SLR $\left.\right|_{\max }$ ) between any two of the four glucose concentrations tested (one SLR for each of the six comparisons possible). The top 40 known or predicted genes (based on Affymetrix annotation file released on 18 March 2008) were then divided into upregulated genes, downregulated genes and V-shaped genes Hybridisation signal intensities (mean $\pm \mathrm{SE}$ ) are shown for each glucose concentration

For each probe-set, one-way ANOVA and SLR and Bonferroni $p$ values for the six comparisons are detailed in ESM Table 5

high proportion ( $\sim 58 \%)$ of these 411 probe-sets had a level of expression in $\mathrm{G} 30$ that was not statistically different from that in $\mathrm{G} 2$ and would have been considered unaffected by glucose in studies comparing only these two extreme glucose concentrations.
The 40 genes most affected by glucose are listed in Table 2 . They include 16 upregulated genes, 19 downregulated genes and five genes with a clear V-shaped profile, of which four were more down- than upregulated by glucose. Among the 16 most upregulated genes, Aldob, Txnip, Crem and Fos are 
known to be strongly induced by high glucose and to contribute to beta cell glucotoxicity [20, 21, 24, 25]. This suggests that other genes with a similar mRNA profile may also favour beta cell glucotoxicity, confer protection against it or be indicators of pathways involved in such processes. Among the 19 most downregulated genes, Dbp, Ddit3 (also known as Chop or Gadd153) and Trib3 have been shown to be highly expressed at low glucose in beta cells $[14,17,19$, 26]. Interestingly, the latter two genes are part of the integrated stress response (ISR), which is activated by oxidative stress, DNA damage, nutrient deprivation, viral infection and endoplasmic reticulum (ER) stress [27]. Surprisingly, Fas, a pro-apoptotic gene previously shown to be upregulated by prolonged exposure to high glucose [28], was highly expressed at low glucose and minimally expressed in G10 and G30. Together with other genes displaying a similar mRNA profile, these genes may play a role in the pro-apoptotic effect of prolonged culture in G2 and G5 instead of in G10 [12-14, 26]. Finally, among genes with a V-shaped profile, Mt1a and Hmoxl are considered good markers of beta cell oxidative stress and seem to confer protection against beta cell apoptosis under stressful conditions $[29,30]$. Other genes with a similar mRNA profile such as Myc and Casp4 may, in contrast, play a role in activation of beta cell apoptosis by oxidative stress. Interestingly in this respect, beta cell apoptosis after prolonged culture in increasing glucose concentrations is V-shaped with a minimum in G10 [11, 14], and beta cell reactive oxygen species production increases at either low or high vs intermediate glucose concentrations [31-34].

Cluster analysis of glucose-affected probe-sets Almost onethird of the islet transcriptome was significantly up- or downregulated more than 1.4-fold across the range of glucose concentrations tested, of which about $8 \%$ was regulated in a complex manner ( $\mathrm{V}$-shaped and inverse-Vshaped profiles). To better characterise the effects of glucose on islet gene mRNA levels, the 5,046 glucoseaffected probe-sets were grouped in 18 clusters by a process involving non hierarchical self-organising map cluster analysis. This allowed us to distinguish probe-sets that were regularly down- or upregulated across the whole range of glucose concentrations from those that were mostly affected within distinct sub-ranges of glucose concentrations and those that presented complex related profiles (Fig. 3). The distribution of probe-sets across these clusters indicates that changes in gene expression occurred predominantly between G5 and G10, and that there were more differences between G10 and G30 than between G2 and G5 samples. Thus, no cluster was exclusively down- or upregulated between G2 and G5, and only 149 probe-sets with complex profiles were affected within that window of glucose concentrations (clusters V3-V4 and P3-P4). In contrast, about $13 \%$ of the probe-sets were significantly affected between G10 and G30, either exclusively (clusters U4-D4) or as part of complex profiles (clusters V1, V2, V4 and P1, P2, P4). The effects of glucose on the mRNA levels of a few selected genes belonging to various clusters were confirmed by real-time RT-PCR (Table 3, ESM Table 3).

Possible biological significance of the different $m R N A$ expression profiles By comparing the expression profiles in Fig. 3 with various glucose-regulated biological responses in islets, one could speculate on the (patho) physiological role of genes belonging to a given cluster or on the factors regulating their mRNA levels. Thus, cluster $\mathrm{U} 1$ has a profile resembling those of glucose-stimulated protein synthesis (Fig. 2a) and rise in ATP : ADP ratio [10], while the profile of cluster U2 is closer to that of glucoseinduced rise in $\left[\mathrm{Ca}^{2+}\right]_{\mathrm{i}}$. In comparison, cluster U3's profile is similar to those of insulin secretion during culture (Fig. 2b) and glucose-induced Xbp1 mRNA splicing [14], a specific marker of unfolded protein response (UPR) activation [35]. Finally, the profiles of clusters V1 to V2 resemble those of long-term glucose-induced changes in ISR gene expression and islet cell apoptosis [14].

To further evaluate the biological significance of these expression profiles, we searched for gene ontology Biological Process categories that were significantly enriched in the ten subgroups of clusters (identified by a rectangle in Fig. 3) using Onto-Express [36] (ESM Table 4). In agreement with previous studies $[8,17-19,21]$, glucose mostly affected the mRNA levels of genes involved in: (1) glucose, lipid and cholesterol metabolic processes; (2) protein synthesis, folding, maturation and intracellular transport; (3) ion handling and exocytosis; (4) DNA synthesis and cell cycle regulation; (5) cell redox homeostasis and responses to oxidative stress and hypoxia; and (6) apoptosis and various catabolic processes. Although gene ontology categories were sometimes enriched in neighbouring clusters, we were able to identify biological processes that are mostly downor upregulated between low and intermediate, intermediate and high, or low and high glucose, as well as processes regulated in a complex manner. To better convey our main findings, we drew biological maps combining selected pathways of interest using MAPP-Builder [37], and coloured genes according to the cluster to which they belong using GenMAPP 2.1 (http://www.genmapp.org, accessed 1 December 2008) [37] (Figs. 4, 5, ESM Fig. 5). When examining these figures, it should be born in mind that the overall islet mRNA profile reflects the mean of phenomena in different cell types. Thus, although most changes are likely to have occurred in beta cells $(\sim 70-80 \%$ of islet mass), some may have occurred in non-beta cells, especially for genes normally disallowed in beta cells like the lactate/pyruvate transporter Mctl (also known as 
Fig. 3 Cluster analysis of glucose-affected probe-sets. After data normalisation (mean $=0$, variance $=1)$, the 5,046 glucose-affected probesets were separated into 18 clusters (for details see ESM Fig. 4). Clusters were exclusively upregulated (U0-U4) $(\mathbf{b}, \mathbf{e}, \mathbf{i}, \mathbf{m}, \mathbf{q})$, exclusively downregulated (D0-D4)

$(\mathbf{a}, \mathbf{d}, \mathbf{h}, \mathbf{l}, \mathbf{p})$, V-shaped (V1V4) $(\mathbf{c}, \mathbf{g}, \mathbf{n}, \mathbf{r})$ or inverse Vshaped (P1-P4) (f, j, k, o). For ease of presentation, clusters were grouped horizontally according to the glucose concentrations between which changes in gene expression predominantly occur (D0 and U0, from G2 to G30; V1, D1, $\mathrm{U} 1$ and $\mathrm{P} 1$, from $\mathrm{G} 2$ to $\mathrm{G} 10$; V2, D2, U2 and P2, from G5 to $\mathrm{G} 10$; P3, D3, U3 and V3, from G5 to G30; P4, D4, U4 and V4, from G10 to G30). Rectangles identify pairs of closely related clusters that are referred to by a single colour in Figs. 4, 5 and ESM Fig. 5. For each cluster, the mean $\pm \mathrm{SD}$ of normalised probe-set signal intensities is shown as a function of the glucose concentration, with the number of probe-sets shown in parentheses. For list of all affected probe-sets with their respective clusters, see ESM Table 5
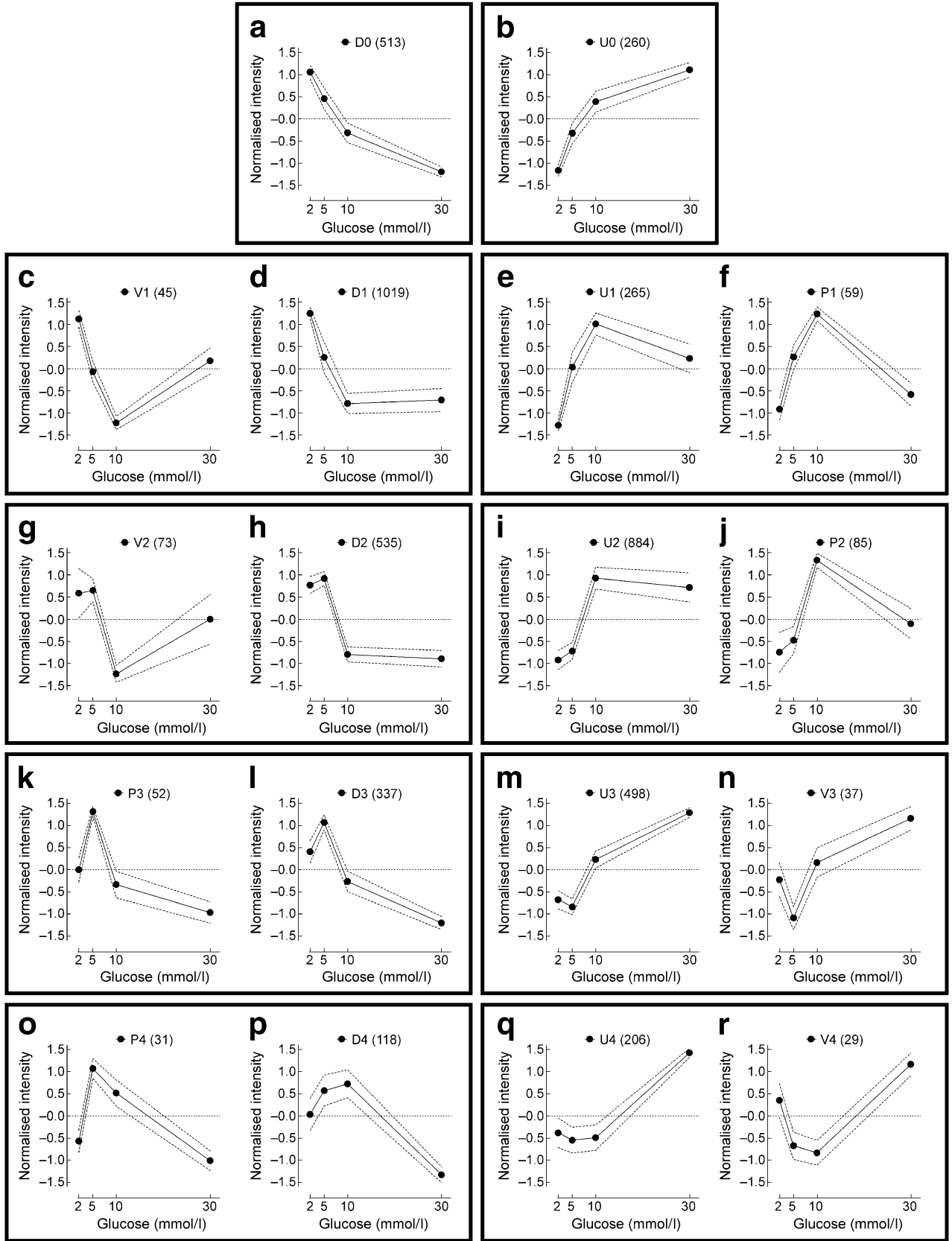

Slc16a1) [1,38]. Please also note that changes in mRNA levels may result from altered transcription or mRNA stability and that the higher level of complexity due to alternative mRNA splicing was not addressed. Finally, changes in mRNA levels may not necessarily lead to parallel changes in protein levels, as glucose influences general translation as well as translation of specific mRNAs by various mechanisms $[39,40]$.

Glucose regulation of islet cell nutrient metabolism, hormone production and ion handling gene mRNA levels As shown in Fig. 4, the mRNA levels of the transcription factors Srebp1 and Srebp2 (also known as Srebf1 and Srebf2, respectively) and of many genes involved in fatty acid synthesis and desaturation, and in cholesterol transport, biosynthesis and esterification were mostly upregulated between G5 and G10 (cluster U2 and, for a few, cluster U3), in parallel with the mRNA levels of Glut2 and glucokinase. These results are in good agreement with a study showing that culture in G10 vs G3 activates expression of cholesterol biosynthetic pathway in purified beta cells [8], indicating that our results are well representative of changes in beta cells. As these effects occur in a range of glucose concentrations that improve beta cell function and survival, it is tempting to speculate that the stimulation of cholesterol biosynthesis may be beneficial to beta cell function. In 
Table 3 Comparison of microarray and real-time RT-PCR measurements of glucose-induced changes in islet gene mRNA levels

Gene symbol Probe-set ID Cluster Signal intensity G10 Threshold cycle G10 Islet gene mRNA levels (relative to G10)

\begin{tabular}{|c|c|c|c|c|c|c|c|c|}
\hline & & & & & \\
\hline & & & & & G2 & G5 & G10 & G30 \\
\hline \multicolumn{9}{|c|}{ Housekeeping gene } \\
\hline$T b p$ & 1382035_at & NA & 134 & & $1.08 \pm 0.02$ & $1.06 \pm 0.07$ & $1.0 \pm 0.08$ & $1.01 \pm 0.07$ \\
\hline$T b p$ & PCR & & & 27.8 & $1.27 \pm 0.07 * *$ & $1.12 \pm 0.06$ & $1.0 \pm 0.05$ & $1.11 \pm 0.05$ \\
\hline \multicolumn{9}{|c|}{ Islet hormones } \\
\hline Ins1 & 1387815_at & $\mathrm{U} 1$ & 9,607 & & $0.68 \pm 0.04 *$ & $0.86 \pm 0.06$ & $1.0 \pm 0.06$ & $0.91 \pm 0.04$ \\
\hline $\operatorname{Ins} 1+\operatorname{Ins} 2$ & $\mathrm{PCR}$ & & & 12.5 & $0.36 \pm 0.05^{*}$ & $0.60 \pm 0.03 *$ & $1.0 \pm 0.10$ & $0.91 \pm 0.09$ \\
\hline$G c g$ & 1369888_at & $\mathrm{U} 1$ & 11,919 & & $0.70 \pm 0.04$ & $0.84 \pm 0.05$ & $1.0 \pm 0.06$ & $0.92 \pm 0.03$ \\
\hline$G c g$ & PCR & & & 16.5 & $0.91 \pm 0.09$ & $1.07 \pm 0.08$ & $1.0 \pm 0.03$ & $0.96 \pm 0.08$ \\
\hline \multicolumn{9}{|l|}{ Metabolism } \\
\hline Aldob & 1370299_at & $\mathrm{U} 4$ & 13 & & $0.93 \pm 0.28$ & $0.62 \pm 0.29$ & $1.0 \pm 0.43$ & $66 \pm 12 *$ \\
\hline Aldob & PCR & & & 32.9 & $1.06 \pm 0.60$ & $0.71 \pm 0.27$ & $1.0 \pm 0.33$ & $116 \pm 1.2 *$ \\
\hline Gapdh & 1367557_s_at & $\mathrm{U} 3$ & 4,156 & & $0.60 \pm 0.03^{*}$ & $0.64 \pm 0.04^{*}$ & $1.0 \pm 0.04$ & $1.61 \pm 0.07^{*}$ \\
\hline Gapdh & PCR & & & 22.3 & $0.67 \pm 0.09^{* *}$ & $0.65 \pm 0.05^{* *}$ & $1.0 \pm 0.05$ & $2.47 \pm 0.09^{*}$ \\
\hline Cycs & 1369939_at & U3 & 2,825 & & $0.48 \pm 0.02 *$ & $0.53 \pm 0.02 *$ & $1.0 \pm 0.05$ & $1.27 \pm 0.06^{*}$ \\
\hline Cycs & 1387773_at & U3 & 1,800 & & $0.64 \pm 0.03 *$ & $0.65 \pm 0.02 *$ & $1.0 \pm 0.02$ & $1.50 \pm 0.04 *$ \\
\hline Cycs & $\mathrm{PCR}$ & & & 25.4 & $0.62 \pm 0.13$ & $0.52 \pm 0.04$ & $1.0 \pm 0.15$ & $1.79 \pm 0.17 *$ \\
\hline \multicolumn{9}{|l|}{ ER stress } \\
\hline Dnajc3 & 1370073_at & U3 & 1,352 & & $0.73 \pm 0.04 *$ & $0.70 \pm 0.02 *$ & $1.0 \pm 0.02$ & $1.34 \pm 0.02 *$ \\
\hline Dnajc3 & PCR & & & 23.2 & $0.70 \pm 0.05^{*}$ & $0.70 \pm 0.04 *$ & $1.0 \pm 0.05$ & $1.34 \pm 0.04 *$ \\
\hline Serp1 & 1386900_at & U3 & 3,499 & & $0.88 \pm 0.04$ & $0.84 \pm 0.07$ & $1.0 \pm 0.05$ & $1.19 \pm 0.04 * *$ \\
\hline Serp1 & 1367686_at & $\mathrm{U} 2$ & 6,958 & & $0.69 \pm 0.01 *$ & $0.78 \pm 0.03 *$ & $1.0 \pm 0.03$ & $0.98 \pm 0.03$ \\
\hline Serp1 & $\mathrm{PCR}$ & & & 25.3 & $1.17 \pm 0.13$ & $1.16 \pm 0.09$ & $1.0 \pm 0.05$ & $1.56 \pm 0.14 *$ \\
\hline Ern1 & 1377213_at & $\mathrm{D} 1$ & 486 & & $2.10 \pm 0.12 *$ & $1.91 \pm 0.11 *$ & $1.0 \pm 0.05$ & $1.14 \pm 0.01$ \\
\hline Ern1 & PCR & & & 26.3 & $1.80 \pm 0.10^{*}$ & $1.91 \pm 0.10^{*}$ & $1.0 \pm 0.09$ & $1.22 \pm 0.09$ \\
\hline Trib3 & 1370695_s_at & $\mathrm{D} 1$ & 167 & & $8.54 \pm 0.57^{*}$ & $7.67 \pm 0.36^{*}$ & $1.0 \pm 0.18$ & $1.65 \pm 0.10$ \\
\hline Trib3 & 1370694_at & D1 & 153 & & $5.45 \pm 0.29 *$ & $4.64 \pm 0.31 *$ & $1.0 \pm 0.17$ & $1.32 \pm 0.10$ \\
\hline Trib3 & 1386321_s_at & D1 & 272 & & $4.97 \pm 0.38^{*}$ & $4.10 \pm 0.21 *$ & $1.0 \pm 0.11$ & $1.28 \pm 0.09$ \\
\hline Trib3 & PCR & & & 30.4 & $10.1 \pm 0.83^{*}$ & $9.08 \pm 0.83 *$ & $1.0 \pm 0.10$ & $2.14 \pm 0.33$ \\
\hline \multicolumn{9}{|c|}{ Oxidative stress } \\
\hline Mt1a & 1371237_a_at & $\mathrm{V} 2$ & 299 & & $14.60 \pm 1.7^{*}$ & $12.60 \pm 2.40 *$ & $1.0 \pm 0.68$ & $4.19 \pm 0.32$ \\
\hline Mt1a & 1388267_a_at & D1 & 26 & & $2.29 \pm 0.25^{*}$ & $1.67 \pm 0.09$ & $1.0 \pm 0.25$ & $1.08 \pm 0.19$ \\
\hline Mt1a & PCR & & & 27.8 & $99.10 \pm 11^{*}$ & $48.30 \pm 4.70^{*}$ & $1.0 \pm 0.17$ & $37.60 \pm 13.1^{* *}$ \\
\hline Hmoxl & 1370080_at & $\mathrm{V} 1$ & 264 & & $4.74 \pm 0.57 *$ & $2.90 \pm 0.50 * *$ & $1.0 \pm 0.31$ & $4.01 \pm 0.83 *$ \\
\hline Hmoxl & PCR & & & 24.3 & $4.60 \pm 0.33^{*}$ & $2.48 \pm 0.24 *$ & $1.0 \pm 0.14$ & $2.83 \pm 0.33^{*}$ \\
\hline Txnip & 1371131_a_at & U4 & 346 & & $0.24 \pm 0.01$ & $0.33 \pm 0.03$ & $1.0 \pm 0.13$ & $11.20 \pm 1.36^{*}$ \\
\hline Txnip & PCR & & & 26.2 & $0.13 \pm 0.04 *$ & $0.20 \pm 0.03 *$ & $1.0 \pm 0.18$ & $13.90 \pm 0.17 *$ \\
\hline \multicolumn{9}{|l|}{ Apoptosis } \\
\hline Myc & 1368308_at & $\mathrm{V} 2$ & 21 & & $4.12 \pm 0.52^{*}$ & $3.71 \pm 0.43^{*}$ & $1.0 \pm 0.28$ & $2.39 \pm 0.10 * *$ \\
\hline$M y c$ & PCR & & & 29.7 & $5.19 \pm 0.64 * *$ & $5.47 \pm 0.55^{* *}$ & $1.0 \pm 0.27$ & $5.00 \pm 1.27 *$ \\
\hline Casp4 & 1387818_at & $\mathrm{V} 2$ & 172 & & $5.06 \pm 0.42 *$ & $5.12 \pm 0.20^{*}$ & $1.0 \pm 0.07$ & $1.98 \pm 0.14 * *$ \\
\hline Casp4 & 1381173_at & $\mathrm{NC}$ & 17 & & $1.97 \pm 0.52$ & $3.52 \pm 0.51 * *$ & $1.0 \pm 0.33$ & $1.19 \pm 0.48$ \\
\hline Casp4 & PCR & & & 28.1 & $7.90 \pm 0.29 *$ & $7.70 \pm 0.32 *$ & $1.0 \pm 0.11$ & $1.71 \pm 0.21$ \\
\hline Fas & 1384842_s_at & $\mathrm{D} 1$ & 22 & & $9.20 \pm 0.68 *$ & $7.52 \pm 0.54^{*}$ & $1.0 \pm 0.23$ & $0.76 \pm 0.14$ \\
\hline Fas & PCR & & & 33.9 & $14.10 \pm 0.89 *$ & $11.6 \pm 0.37 *$ & $1.0 \pm 0.12$ & $1.01 \pm 0.42$ \\
\hline
\end{tabular}

After 1 week pre-culture in G10, islets were cultured for $18 \mathrm{~h}$ in G2, G5, G10 or G30. Glucose-induced changes in the mRNA levels of selected genes belonging to various clusters were confirmed by real-time RT-PCR using islet cDNA from cultures distinct from those used for microarray experiments.

Gene mRNA levels are expressed relative to the level in G10, data are means \pm SE for three (real-time RT-PCR) and four (microarray) experiments. The mean signal intensity (microarray) and threshold cycle measured in G10 (real-time PCR performed with islet cDNA equivalent to 2 ng total RNA) are shown as rough indicators of gene mRNA levels

${ }^{*} p<0.05, * * p<0.01$ vs islets cultured in G10 (one-way ANOVA and Newman-Keuls test)

NA, not affected 


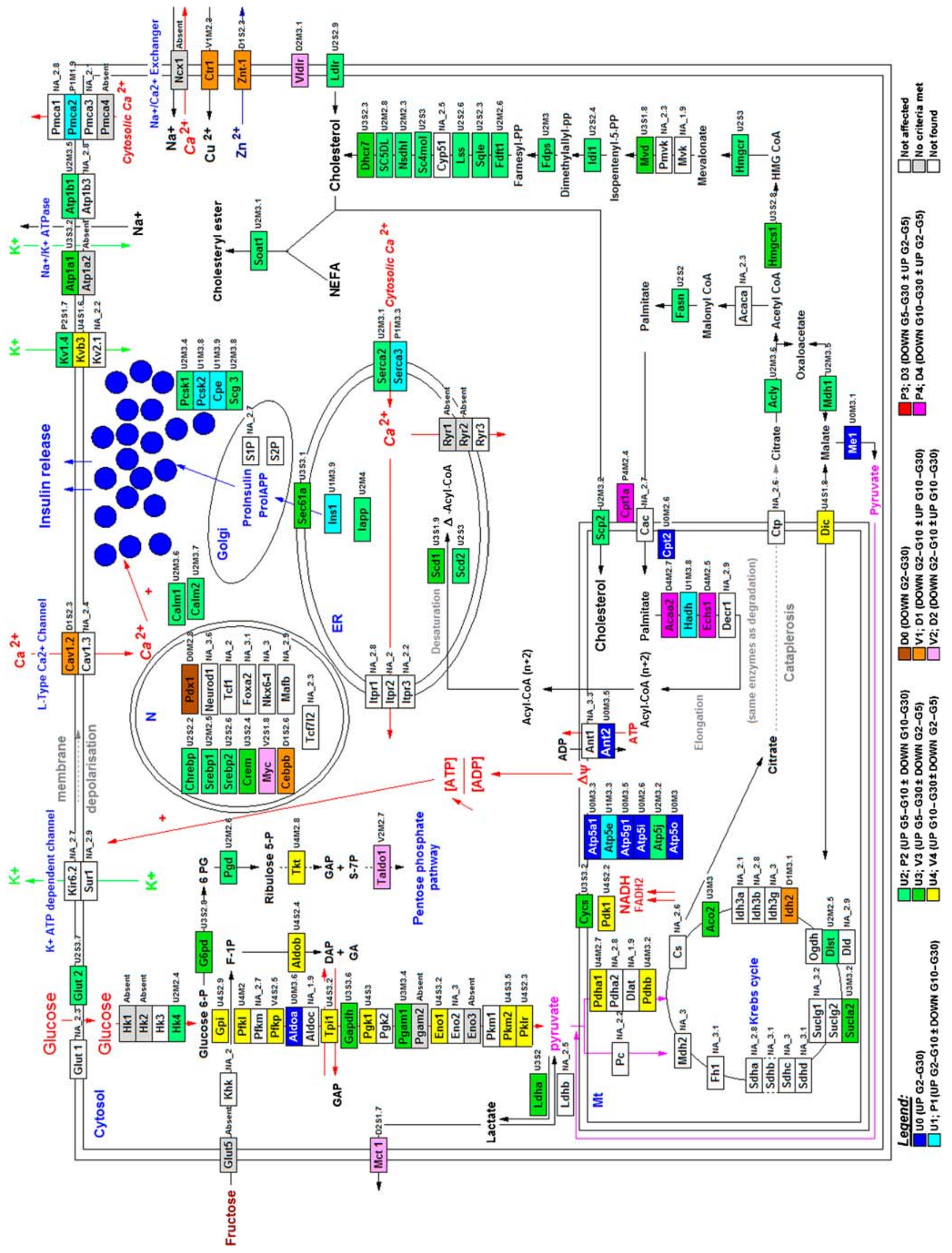


4 Fig. 4 Glucose-induced changes in the mRNA levels of genes involved in islet cell nutrient metabolism, hormone production and ion handling. New biological maps were created by combining selected biological maps of interest available on GenMAPP database with data from the literature and various public databases using MAPP Builder software [37]. Genes involved in selected metabolic and signalling pathways were then coloured according to the cluster or pair of clusters to which they belong using GenMAPP 2.1 (cluster pairs as in Fig. 3). The sequence of letters and numbers shown to the right of each gene box corresponds to (from left): (1) the cluster to which the gene belongs; (2) a letter indicating if the gene is affected by glucose more than twofold (S) or between 1.4- and twofold (M); and (3) the log-transformed mean signal intensity across the whole range of glucose concentrations. NA, not affected. Boxes display the up-to-date gene symbols, except for the following aliases: Ant1 (Slc24a4), Cac (Slc25a20), Cav1.2 (Cacna1c), Cav1.3 (Cacna1d), Chrebp (Mlxipl), Ctp (Slc25al), Dic (Slc25a10), Glut1 (Slc2al), Glut2 (Slc2a2), Glut5 (Slc2a5), Ctr1 (Slc31a1), Kir6.2 (Kcnj11), Kvb3 (Kcnab3), Kv1.4 (Knca4), Kv2.1 (Kcnb1), Ncx1 (Slc8a1), Pmcal (Atp2b1), Pmca2 (Atp2b2), Pmca3 (Atp2b3), Pmca4 (Atp2b4), Serca2 (Atp2a2), Serca3 (Atp2a3), Sur1 (Abcc8), S1p (Mbtps1), Tcf1 (Pcbd1), Znt-1 (Slc30a1). 6 PG, 6-phosphogluconate; DAP, dihydroxyacetone phosphate; dimethylallyl-pp, dimethylallyl diphosphate; farnesyl-PP, farnesyl diphosphate; F-1P, fructose 1-phosphate; GA, glyceraldehyde; GAP, glyceraldehyde 3-phosphate; glucose 6-P, glucose 6phosphate; HMG-coA, 3 hydroxy-3-methylglutaryl-coenzyme A; isopentyl-5-PP, isopentyl 5-diphosphate; Mt, mitochondrion; proIAPP, proislet amyloid polypeptide; ribulose 5-P, ribulose 5-phosphate; S-7P, sedoheptulose 7-phosphate

support of that hypothesis, cholesterol depletion and Srebplc (also known as Srebfl) gene inactivation significantly altered beta cell function [41, 42]. However, the fact that Srebplc and Srebp 2 overexpression are also deleterious to beta cell differentiation and function [43, 44] suggests that both excessive and insufficient cholesterol availability is harmful to beta cells. Thus, the cholesterol biosynthesis pathway needs to be tightly regulated for optimal preservation of the beta cell phenotype.

Figure 4 also shows that the mRNA levels of genes coding for most glycolytic enzymes (at least one isoform thereof), except glucokinase (Hk4), were predominantly upregulated between G10 and G30 (cluster U4 and, for a few, U3), in parallel with the mRNA levels of enzymes of the pentose-phosphate pathway, a few mitochondrial metabolism enzymes, pyruvate dehydrogenase kinase isoenzyme 1 and cytochrome c. The glucose regulation of glycolytic enzyme expression, which is compatible with previous studies in INS1 and cultured rat islets [21, 45], may reflect a state of relative hypoxia that may contribute to beta cell glucotoxicity. In support of this hypothesis, we recently observed that culture in G30 activates the hypoxiainducible transcription factor and expression of its specific target gene adrenomedullin (Table 2) in a $\mathrm{pO}_{2}$-sensitive manner in whole rat islets and INS1-cell monolayers (M. Bensellam and J. C. Jonas, unpublished results).

In addition, Fig. 4 shows the most important changes in the mRNA levels of mitochondrial enzymes involved in nutrient-induced rise in ATP production and of proteins involved in islet ion handling, hormone production and processing. Interestingly, the mRNA levels of Ant2 (also known as Slc25a5) and various ATP synthase subunits were moderately increased by glucose (cluster U0). As leucine stimulation of ATP synthase expression in INS1-cells increased subsequent GSIS [46], such an effect could also contribute to the higher glucose-responsiveness of islets cultured in G10 and G30 vs G2 and G5. Of note, mRNA levels of the ATP-sensitive $\mathrm{K}^{+}$channel subunits $A b c c 8$ (also known as Sur1) and Kcnj11 (also known as Kir6.2) were not affected by glucose, contrary to previous findings in purified beta cells [8]. In contrast, mRNA levels of proinsulin, proislet amyloid polypeptide and most hormone-processing enzymes were upregulated in a range of glucose concentrations favouring beta cell function and survival (from G2 to G10). Finally, Fig. 4 lists some of the transcription factors involved in beta cell differentiation or in glucotoxicity such as Crem, Myc and Cebpb [15, 20,47]. Surprisingly, Cebpb mRNA levels were mostly downregulated between G2 and G10, suggesting its possible involvement in beta cell apoptosis during prolonged culture in low glucose. On the other hand, Myc mRNA profile was V-shaped with a minimum in G10 and a larger increase at low than at high glucose, in parallel with the mRNA levels of oxidative stress response genes Hmoxl and Mtla. Its possible role in the induction of beta cell apoptosis at low and high glucose has been discussed elsewhere [13, 15, 23].

Glucose regulation of UPR and ISR gene mRNA levels We previously reported that the pharmacological ER stress inducer thapsigargin increases both UPR and ISR gene expression in cultured rat islets. In contrast, glucose (between G5 and G30) rapidly stimulates the unconventional splicing of Xbpl pre-mRNA by the endoribonuclease kinase ERN1 (previously known as IRE1 $\alpha$ ) and increases the mRNA levels of XBP1-target genes characteristic of the UPR in a protein synthesis-dependent manner while exerting complex effects on the expression of ATF4-target genes typically induced by the ISR, with downregulation between G2-G5 and G10, and little increase between G10 and G30 [14]. The notion that glucose differently affects the UPR and ISR in cultured rat islets has gained further support through the present study. Thus, many genes involved in protein folding, ER to Golgi transport and ER-associated degradation pathway, e.g. Serp1 (also known as Ramp4), Dnajc3 (also known as P58Ipk), several subunits of the coatomer protein complex, various foldases, chaperones and co-chaperones, etc., have an mRNA profile close to that of Xbpl mRNA splicing (cluster U3 and, for a few, U2; Table 3, Fig. 4). Among these putative XBP1-target genes [35], Dnajc3 could mediate a negative feedback of the UPR on ISR activation by inhibiting PERK (EIF2AK3) activity [48]. Such feedback 


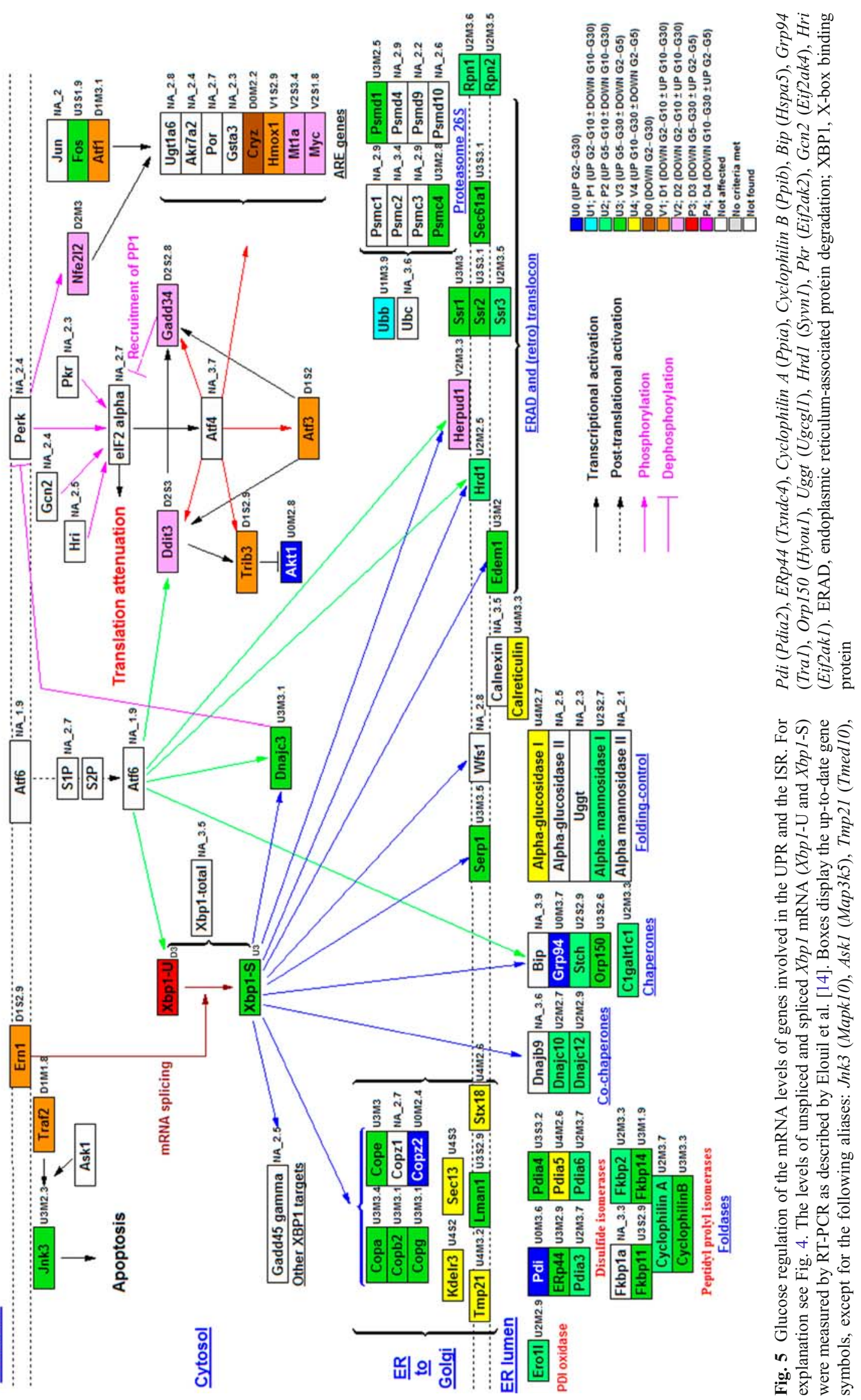


may contribute to some extent to the opposite regulation of the UPR and ISR between G5 and G10. In contrast, ATF4target genes such as Atf3, Ddit3, Gadd34 and Trib3 were downregulated between G5 and G10, and little affected between G10 and G30 (clusters D1-D2; Table 3, Fig. 5). As suggested earlier, these ISR genes may contribute to beta cell apoptosis during prolonged culture in low glucose. This list of genes was extended to $\mathrm{Nfe} 2 \mathrm{l} 2$ which codes for a transcription factor, activated by PERK, that regulates the expression of genes containing an antioxidant response element in their promoter, such as Mtla and $M y c$. We also observed downregulation of the mRNA levels of Ern1 (Table 3, Fig. 5). This observation suggests the possibility of a positive feedback of the ISR on the XBP1 branch of the UPR, if ERN1 protein levels were also increased at low glucose.

Other effects of glucose on islet gene mRNA levels Among other important findings, the gene ontology biological process category apoptosis was enriched in clusters D1+V1 while anti-apoptosis was enriched in cluster U0 (ESM Table 4). We therefore drew a map depicting the effects of glucose on the mRNA levels of genes involved in the main apoptotic pathways (ESM Fig. 5). Apart from Myc, Casp4 was the only pro-apoptotic gene with a V-shaped mRNA profile resembling that of beta cell apoptosis after prolonged culture of fresh or 1 week pre-cultured islets (Fig. 1a, [14]). Interestingly, this inflammatory caspase, which is essential for LPS-induced endotoxic shock, is produced as a procaspase that can process itself in vitro [49]. Its increased expression may therefore play a role in the stimulation of beta cell apoptosis during prolonged culture in low or high glucose. However, other pro-apoptotic genes belonging to clusters D1 and D2, such as Ddit3, Cd40, Fas etc., could contribute to beta cell apoptosis at low glucose, whereas genes belonging to clusters $\mathrm{U} 3, \mathrm{~V} 3$ and $\mathrm{U} 4$, such as Casp 7 and the TNF $\alpha$ receptor Tnfrsfla, may play a role in beta cell apoptosis at high glucose. Interestingly, the present study confirmed our previous observation that glucose does not affect the islet mRNA levels of interleukin- $1 \beta$ under our culture conditions [50].

Conclusion The effects of glucose on islet gene expression are complex and not limited to the up- or downregulations described in two-state models. Combining cluster analysis of the various glucose-dependent mRNA profiles with Gene Ontology functional classification allowed the identification of pathways that may play a role in the alterations of beta cell function and survival after culture in the presence of low or high vs intermediate glucose concentrations. These results should help identify the pathways involved in the phenotypic plasticity of pancreatic beta cells under states of chronic hypo- or hyperglycaemia.
Acknowledgements We thank A. Dannau and F. Knockaert for expert technical help, and Y. Guiot (Service of Pathology, UCL) for islet histology. This work was supported by Grants 3.4506.05 from the Fonds de la Recherche Scientifique Médicale (Belgium), Grant ARC 05/10-328 from the General Direction of Scientific Research of the French Community of Belgium and the Interuniversity Poles of Attraction Program (P6/42)Belgian Science Policy. It was also supported by Grant GOA 2004-11 to F. C. Schuit, and the Centre of Excellence SymBioSys (Research Council KULeuven EF/05/007) to F. C. Schuit and L. Overbergh. M. Bensellam is Research Fellow and J. C. Jonas is Senior Research Associate of the Fonds de la Recherche Scientifique-FNRS (Belgium).

Duality of interest The authors declare that there is no duality of interest associated with this manuscript.

\section{References}

1. Quintens R, Hendrickx N, Lemaire K, Schuit F (2008) Why expression of some genes is disallowed in beta-cells. Biochem Soc Trans 36:300-305

2. Weir GC, Laybutt DR, Kaneto H, Bonner-Weir S, Sharma A (2001) $\beta$-cell adaptation and decompensation during the progression of diabetes. Diabetes 50(Suppl 1):S154-S159

3. Blume N, Skouv J, Larsson LI, Holst JJ, Madsen OD (1995) Potent inhibitory effects of transplantable rat glucagonomas and insulinomas on the respective endogenous islet cells are associated with pancreatic apoptosis. J Clin Invest 96:2227-2235

4. Leahy JL (2000) Detrimental effects of chronic hyperglycemia on the pancreatic $\beta$-cell. In: LeRoith D, Taylor SI, Olefsky JM (eds) Diabetes mellitus: a fundamental and clinical text. LippincottWilliams \& Wilkins, Philadelphia, pp 115-124

5. Hinke SA, Hellemans K, Schuit FC (2004) Plasticity of the $\beta$ cell insulin secretory competence: preparing the pancreatic $\beta$ cell for the next meal. J Physiol 558:369-380

6. Cnop M, Welsh N, Jonas JC, Jorns A, Lenzen S, Eizirik DL (2005) Mechanisms of pancreatic $\beta$-cell death in type 1 and type 2 diabetes: many differences, few similarities. Diabetes 54(Suppl 2): S97-S107

7. Gilon P, Jonas JC, Henquin JC (1994) Culture duration and conditions affect the oscillations of cytoplasmic calcium concentration induced by glucose in mouse pancreatic islets. Diabetologia 37:1007-1014

8. Flamez D, Berger V, Kruhoffer M, Orntoft T, Pipeleers D, Schuit FC (2002) Critical role for cataplerosis via citrate in glucoseregulated insulin release. Diabetes 51:2018-2024

9. Ling Z, Kiekens R, Mahler T et al (1996) Effects of chronically elevated glucose levels on the functional properties of rat pancreatic $\beta$-cells. Diabetes 45:1774-1782

10. Khaldi MZ, Guiot Y, Gilon P, Henquin JC, Jonas JC (2004) Increased glucose sensitivity of both triggering and amplifying pathways of insulin secretion in rat islets cultured for one week in high glucose. Am J Physiol Endocrinol Metab 287: E207-E217

11. Efanova IB, Zaitsev SV, Zhivotovsky B et al (1998) Glucose and tolbutamide induce apoptosis in pancreatic $\beta$-cells - a process dependent on intracellular $\mathrm{Ca}^{2+}$ concentration. J Biol Chem 273:33501-33507

12. Hoorens A, van de Casteele M, Klöppel G, Pipeleers DG (1996) Glucose promotes survival of rat pancreatic $\beta$ cells by activating synthesis of proteins which suppress a constitutive apoptotic program. J Clin Invest 98:1568-1574

13. Van de Casteele M, Kefas BA, Cai Y et al (2003) Prolonged culture in low glucose induces apoptosis of rat pancreatic $\beta$-cells 
through induction of c-myc. Biochem Biophys Res Commun 312:937-944

14. Elouil H, Bensellam M, Guiot $Y$ et al (2007) Acute nutrient regulation of the unfolded protein response and integrated stress response in cultured rat pancreatic islets. Diabetologia 50:14421452

15. Jonas JC, Laybutt DR, Steil GM et al (2001) High glucose stimulates early response gene c-Myc expression in rat pancreatic $\beta$ cells. J Biol Chem 276:35375-35381

16. Jonas JC, Guiot Y, Rahier J, Henquin JC (2003) Haeme-oxygenase 1 expression in rat pancreatic beta-cells is stimulated by supraphysiological glucose concentrations and by cyclic AMP. Diabetologia 46:1234-1244

17. Webb GC, Akbar MS, Zhao C, Steiner DF (2000) Expression profiling of pancreatic $\beta$ cells: glucose regulation of secretory and metabolic pathway genes. Proc Natl Acad Sci U S A 97:57735778

18. Schuit F, Flamez D, de Vos A, Pipeleers D (2002) Glucoseregulated gene expression maintaining the glucose-responsive state of $\beta$-cells. Diabetes 51(Suppl 3):S326-S332

19. Shalev A, Pise-Masison CA, Radonovich M et al (2002) Oligonucleotide microarray analysis of intact human pancreatic islets: identification of glucose-responsive genes and a highly regulated TGFb signaling pathway. Endocrinology 143:3695-3698

20. Zhou YP, Marlen K, Palma JF et al (2003) Overexpression of repressive cAMP response element modulators in high glucose and fatty acid-treated rat islets. A common mechanism for glucose toxicity and lipotoxicity? J Biol Chem 278:51316-51323

21. Ma Z, Portwood N, Brodin D, Grill V, Bjorklund A (2007) Effects of diazoxide on gene expression in rat pancreatic islets are largely linked to elevated glucose and potentially serve to enhance $\beta$-cell sensitivity. Diabetes 56:1095-1106

22. Sekine N, Cirulli V, Regazzi R et al (1994) Low lactate dehydrogenase and high mitochondrial glycerol phosphate dehydrogenase in pancreatic $\beta$-cells. Potential role in nutrient sensing. J Biol Chem 269:4895-4902

23. Pascal SM, Guiot Y, Pelengaris S, Khan M, Jonas JC (2008) Effects of c-MYC activation on glucose stimulus-secretion coupling events in mouse pancreatic islets. Am J Physiol Endocrinol Metab 295:E92-E102

24. Susini S, Roche E, Prentki M, Schlegel W (1998) Glucose and glucoincretin peptides synergize to induce c-fos, c-jun, junB, zif-268, and nur-77 gene expression in pancreatic b(INS-1) cells. FASEB J 12:1173-1182

25. Chen J, Saxena G, Mungrue IN, Lusis AJ, Shalev A (2008) Thioredoxin-interacting protein: a critical link between glucose toxicity and $\beta$-cell apoptosis. Diabetes 57:938-944

26. Greenman IC, Gomez E, Moore CE, Herbert TP (2007) Distinct glucose-dependent stress responses revealed by translational profiling in pancreatic $\beta$-cells. J Endocrinol 192:179-187

27. Harding HP, Zhang Y, Zeng $\mathrm{H}$ et al (2003) An integrated stress response regulates amino acid metabolism and resistance to oxidative stress. Mol Cell 11:619-633

28. Maedler K, Spinas GA, Lehmann R et al (2001) Glucose induces $\beta$-cell apoptosis via upregulation of the Fas receptor in human islets. Diabetes 50:1683-1690

29. Clark JE, Foresti R, Green CJ, Motterlini R (2000) Dynamics of haem oxygenase-1 expression and bilirubin production in cellular protection against oxidative stress. Biochem J 348:615-619

30. Li X, Chen H, Epstein PN (2004) Metallothionein protects islets from hypoxia and extends islet graft survival by scavenging most kinds of reactive oxygen species. J Biol Chem 279:765-771

31. Bindokas VP, Kuznetsov A, Sreenan S, Polonsky KS, Roe MW, Philipson LH (2003) Visualizing superoxide production in normal and diabetic rat islets of Langerhans. J Biol Chem 278:9796-9801
32. Robertson RP, Harmon J, Tran PO, Tanaka Y, Takahashi H (2003) Glucose toxicity in $\beta$-cells: type 2 diabetes, good radicals gone bad, and the glutathione connection. Diabetes 52:581-587

33. Martens GA, Cai Y, Hinke S, Stange G, van de Casteele M, Pipeleers D (2005) Glucose suppresses superoxide generation in metabolically responsive pancreatic $\beta$ cells. J Biol Chem 280:20389-20396

34. Cai Y, Martens GA, Hinke SA, Heimberg H, Pipeleers D, van de Casteele M (2007) Increased oxygen radical formation and mitochondrial dysfunction mediate beta cell apoptosis under conditions of AMP-activated protein kinase stimulation. Free Radic Biol Med 42:64-78

35. Lee AH, Iwakoshi NN, Glimcher LH (2003) XBP-1 regulates a subset of endoplasmic reticulum resident chaperone genes in the unfolded protein response. Mol Cell Biol 23:7448-7459

36. Draghici S, Khatri P, Bhavsar P, Shah A, Krawetz SA, Tainsky MA (2003) Onto-Tools, the toolkit of the modern biologist: OntoExpress, Onto-Compare, Onto-Design and Onto-Translate. Nucleic Acids Res 31:3775-3781

37. Dahlquist KD, Salomonis N, Vranizan K, Lawlor SC, Conklin BR (2002) GenMAPP, a new tool for viewing and analyzing microarray data on biological pathways. Nat Genet 31:19-20

38. Otonkoski T, Jiao H, Kaminen-Ahola N et al (2007) Physical exerciseinduced hypoglycemia caused by failed silencing of monocarboxylate transporter 1 in pancreatic $\beta$ cells. Am J Hum Genet 81:467-474

39. Vander Mierde D, Scheuner D, Quintens R et al (2006) Glucose activates a PP1 mediated signaling pathway to enhance overall translation in pancreatic $\beta$-cells. Endocrinology 148:609-617

40. Plaisance V, Abderrahmani A, Perret-Menoud V, Jacquemin P, Lemaigre F, Regazzi R (2006) MicroRNA-9 controls the expression of Granuphilin/Slp4 and the secretory response of insulin-producing cells. J Biol Chem 281:26932-26942

41. Diraison F, Ravier MA, Richards SK, Smith RM, Shimano H, Rutter GA (2008) SREBP1 is required for the induction by glucose of pancreatic $\beta$-cell genes involved in glucose sensing. J Lipid Res 49:814-822

42. Vikman J, Jimenez-Feltstrom J, Nyman P, Thelin J, Eliasson L (2008) Insulin secretion is highly sensitive to desorption of plasma membrane cholesterol. FASEB J doi:10.1096/fj.08-105734

43. Wang H, Kouri G, Wollheim CB (2005) ER stress and SREBP-1 activation are implicated in $\beta$-cell glucolipotoxicity. J Cell Sci 118:3905-3915

44. Shimano H, Amemiya-Kudo M, Takahashi A, Kato T, Ishikawa M, Yamada N (2007) Sterol regulatory element-binding protein-1c and pancreatic $\beta$-cell dysfunction. Diabetes Obes Metab 9(Suppl 2):133139

45. Roche E, Assimacopoulos-Jeannet F, Witters LA et al (1997) Induction by glucose of genes coding for glycolytic enzymes in a pancreatic $\beta$-cell line (INS-1). J Biol Chem 272:3091-3098

46. Yang J, Wong RK, Park M et al (2006) Leucine regulation of glucokinase and ATP synthase sensitizes glucose-induced insulin secretion in pancreatic $\beta$-cells. Diabetes 55:193-201

47. Seufert J, Weir GC, Habener JF (1998) Differential expression of the insulin gene transcriptional repressor CCAAT/enhancerbinding protein beta and transactivator islet duodenum homeobox-1 in rat pancreatic beta cells during the development of diabetes mellitus. J Clin Invest 101:2528-2539

48. Yan W, Frank CL, Korth MJ et al (2002) Control of PERK eIF2a kinase activity by the endoplasmic reticulum stress-induced molecular chaperone P58IPK. Proc Natl Acad Sci U S A 99:15920-15925

49. Kang SJ, Wang S, Hara H et al (2000) Dual role of caspase-11 in mediating activation of caspase-1 and caspase-3 under pathological conditions. J Cell Biol 149:613-622

50. Elouil H, Cardozo AK, Eizirik DL, Henquin JC, Jonas JC (2005) High glucose and hydrogen peroxide increase c-Myc and haemeoxygenase 1 mRNA levels in rat pancreatic islets without activating NFkB. Diabetologia 48:496-505 